\title{
India's Missing Daughters: An Ominous Sign for Democracy
}

\author{
Keshab Chandra Ratha \\ Lecturer, Saraswat Degree Mahavidyalaya (Sambalpur University), Godbhaga, \\ PIN-768111, Dist-Sambalpur, Odisha, India. \\ Email:keshab_ratha@rediffmail.com
}

\section{Sushanta Kumar Mahapatra}

Post-Doctoral Fellow (India for European Union-Erasmus Mundus Programme) at Department of Economics, University of Bologna, Strada Maggiore 45 - 40125, Bologna, Italy, Office 19, Associate Professor (Economics), Amrita School of Business, Amrita University, Amrita Institute of Medical Science (AIMS) Campus, Ponekkara Post, Kochi-682 041, Kerala, India,

Doi:10.5901/mjss.2014.v5n13p467

E-mail: sushanta.mahapatra@gmail.com ; sushanta_mahapatra@asb.kochi.amrita.edu

\begin{abstract}
The continuing devaluation of women in economic and social domain, lack of property rights and the increasing scourge of dowry are found for strengthening son preference trends as reflected in the current census figures. The drop in girl child sex ratio may be attributed the notorious nexus of tradition and technology. The collusion between people, the medical fraternity and the administration has resulted in worsening of the sex ratio and failure of the Act to make a difference. Patriarchy is the root cause for the institution of male rule and subordination of female in the society. Bringing daughters is viewed as a liability and sons are preferred as the saviors of seven generation of ancestors. A hardened conscience and disregard for the sanctity of life is the reason for widespread abortion and female foeticide. The skewed sex ratio seems to impact both the treatment of Indian women in particular as well as the health of Indian democracy in general. Reversal of the declining trend is a must to ensure stable economic and societal growth. Progammes that aim to reduce the excessive son preference and increase the value of daughters to their parents should be given top priority.
\end{abstract}

Keywords: Sex ratio, missing women, sex determination, female foeticide, son preference.

\section{Introduction}

The disparity in sex ratio illustrating the population of many Asian countries has grounded a number of authors to argue that there is considerable excess female mortality in Asia. Broadly, they argue that abandon of female children and deprived conditions for women add to the dreadfully low percentage of females in the population ${ }^{1}$. The loss of female children due to sex selective abortions \& female infanticides will create an unbalanced sex structure of the population in the country \& will have serious demographic \& social consequences. Moreover, these practices reflect the social discrimination against the females $\&$ are in serious violation of fundamental human rights of women $\&$ children. They also do not conform to the principle of gender equality in a modern civilized society \& beg the attention of the government \& society at large for their reprisal. The offspring selection favoring man is prevalent, thereby indicating that the life of female is not valued, but actually despised. The speed of clinics offering sex determination tests \& abortion services in the country during last two decades facilitates the increased use of these techniques.

Prior theoretical and empirical economic arguments on gender imbalance emphasized on household level economic incentive affecting imbalance in sex ratios ${ }^{2}$. It is a matter of deep concern that the girl child sex ratio had dropped from 927 to 914 girls per thousand boys, confirming the worst apprehensions of those working to uphold women's rights. It has raised serious concerns about the direction of development which was leading to growth without social justice. The continuing devaluation of women in economic \& social sphere, the lack property rights, and the increasing scourge of dowry were visibly \& tragically strengthening son preference trends, reflected in the current census

${ }_{1}^{1}$ For detailed discussion see Sen 1990; Coale 1991; Klasen 1994.

2 See In this context for income sides (Becker 1991, Rose 1999), earning opportunities for women (Bardhan, 1974; Rosenzweig and Schultz, 1987, Duflo 2001, Qian 2008) and the status of women within different kinship systems (Dyson and Moore 1993, \& Chakraborty and Kim 2010). 
2011 figures $^{3}$. The literature on sex ratio highlights on the function of siblings in son preference. It is well established that preference against a daughter is strongest in the absence of a son ${ }^{4}$. There are also studies that put forth biological factors, to elucidate the sex ratio imbalance ${ }^{5}$. The total failure of central government \& official agencies to take necessary steps to reverse the trends was reprehensible. Preliminary data from 2011 census have recorded many districts with sex ratios of less than 850 . The ratio in urban areas is significantly lower than those in rural parts of the country. Reports suggest evidence of violence \& trafficking of poor women \& forced polyandry in some regions with markedly skewed ratios. The overall steep \& consistent decline in the ratio needs serious review.

The all India sex ratio in 914 girls for 1,000 boys, which puts the country right at the bottom of global charts, worse off than countries like Nigeria (965) \& neighbour Pakistan (958). According to the report, only China with whom ironically, India is competing in economic growth sweepstakes-with 832 girls per 1,000 boys ranks below India. Unsurprisingly, the state of Punjab is cited as the worst offender-the ratio has dropped from 875 in 1991 to 798 girls for every 1,000 boys in 2001. The worsening in the country's hugely skewed sex- ratio is largely due to misuse of pre-natal diagnostic technique despite stringent laws banning their use for sex selection \& consequent increase in cases of female foeticide ${ }^{6}$.

Advance science \& technology has had its adverse effects. The sex-selection in a globalised economy had dragged even the foetus to the market place. Atrocities against women in various forms have been an integral part of the civilization since ages. However, India has unabashedly been home to some barbaric acts against this gentler breed of humanity, starting from dowry deaths \& sati, going up to female infanticide \& female foeticide. In spite of a massive influx of legal regulations barring the female foetuses technology facilitates a series of selective abortions after pre-natal sex determination, techniques such as Amniocentesis were introduced in 1975 to identify any genetic abnormalities. Sadly, these were become tool for sex determination \& proved to be a call of death for tiny unborn female foetuses. What is most alarming is that the Child Sex Ratio (CSR) is mere skewed in "Bermuda Triangle" which includes the land rich \& affluent lands of Punjab, Haryana \& UP. The national capital, New Delhi, is also known to be on the top of the list? Against this backdrop, the aim of this study is to analyze the reasons why the proportion of baby girls is steadily declining.

\section{Inter-state Child Sex Ratio (CSR): Highlights in 2011 Census}

The lowest-ever child sex ratio of 914 over shadowed an increase in the overall sex ratio, which is now 940-the highest nation wise since census 1971 \& a shade lower than 1961-as it reflects a continued preference for a male child. The overall sex ratio (number of females for every 1,000 ratio) has shown improvement, from 932.91 in 2001 to 940.27 in 2011; a good part of this can be explained by the greater national longivity of women \& improvements in health care over the years. It is unfortunate that there has been a steep fall in the child sex ratio, which measures the numbers of girls for every 1,000 boys in the age 0-6 year's age group. The sex ratio in the 0-6 age group has been continually declining since 1961 but the fall from 927.31 in 2001 to 914.23 in 2011 is worst since independence. This trend \& scale of decline in rising India is shocking.

The child sex ratio (0-6 years) in Haryana \& Punjab is lowest among all states. Haryana has 830 female children \& Punjab 846 against per 1000 male child. The highest child sex ratio is in Mizoram (971 females against 1000 males) \& Meghalaya (970 females). At the district level, Lahul \& Spiti in Himachal Pradesh had the highest sex ratio in the age group of 0-6 at 1,013 while in Twang (Arunachal Pradesh) it was 1,005. It was shamefully low in Jhajjar \& Mahendragarh (Haryana) at $774 \& 778$.

The census figures indicate an increase in sex ratio in 29 states \& Union territories, with women out numbering men in Kerala. There were 1,084 women against 1,000 men in Kerala, followed by Puduchery where the figure was 1038. Daman \& Due has a sex ratio of 618 , next only to Dadra \& Nagar Haveli at 775 . Among the districts, Mahe (Puducherry) was the highest sex ratio of 1,176, followed by Almora in Uttarakhand, where it is 1,142. In Daman, it is lowest at 533, \& in Leh of Ladakh, it is 583. The three major states of Jammu \& Kashmir, Bihar \& Gujrat have shown a decline in the sex ratio compared with the figures of census 2001, while 29 states \& Union territories have shown an increase ${ }^{8}$.

In Orissa, census 2011 does not bring good tidings for the girl child in Orissa. There has been significant drop in the number of girls from the last census. Their ratio till the age of six vi-a-vis boys has declined from 953 in 2001 to 934 in

\footnotetext{
${ }^{3}$ All India Democratic Women's Association (AIDWA) 2011.

4 See in this context Bhat and Zavier 2007.

${ }^{5}$ More discussion see in this context Norberg 2004; Oster 2005.

${ }^{6}$ For more elaborated discussion see infochangeindia.org, accessed on 30 June 2011

${ }^{7}$ As quoted from http://www.savegirlchild.org/declining sex_ratio-html

${ }^{8}$ As Reported by Dhar (2011)
} 
2011 (as against 1,000 boys). Of the total 50,35 lakh children surveyed in the state, 26.03 lakh are boys, while 24.32 lakh are girls. Among Eastern states, Orissa cuts the poor figure projecting a count of 934 girls in comparison to 1,000 boys. The neighboring states like Chhattisgarh, Jharkhand, Andhra Pradesh \& West Bengal have 964,943,943 \& 950 respectively. But the girl child population of Orissa is better than many northern Indian states (Punjab, Haryana \& Delhi). Compared to the all India child sex ratio of 914 , it is slightly better have in Orissa but the rate of decline was faster (1.9\%) compared to the national average (1.4\%) in the decade 2001-11. The state has been witnessing in the steady decline in sex ratio in the same age group since 1971. From 1,168 in 1971, it fell to 995 in 1981 \& 967 in 1991. But the 1971 figure was an improvement over 1961's 1,0359.

The census 2011 made a clear revelation that the child sex ratio had dropped from 927 to 914 girls per thousand boys, confirming the worst apprehensions of those working to uphold women's rights. The statistics once again raised serious questions about the direction of development which was leading to "growth" without social justice. It can only be explained by the deadly application of the son preference on a growing scale- though the instrumentality of sex-selective abortion or female foeticide. Attempts to tackle female foeticide through bans on sex-determination tests have been largely ineffective. In his essay "Many faces of gender inequality", (Frontline, November 9, 2001). Amartya Sen drew on 2001 census data to highlight the fact that India split into two when it came to the sex ratio in the 0-6 age group: the South \& the East had a decent ratio revealed a deeply disturbing picture. Even though the regional spilt concealed many micro level variations, the contrast was striking. Despite progress made in the economic \& educational fronts, the biased mindset against the girl child is still a reality. This fact has a direct link to poverty, which needs to address with greater vigour. Female foeticide may be the primary reason for the worsening scenario, but it is certainly not only the one. Most couples, whose first-born are boys do not have a second child. It is not the same if the first born is a girl. We must address gender discrimination seriously, lest the democratic imbalance should have serious consequences ${ }^{10}$.

The 2011 census sounds an alarm over the falling child sex ratio. It is not the poorest \& least illiterate people \& communities who are responsible to it, to the contrary, the reverse is true. The census 2011 shows that the states with worst child sex ratio (CSR) are not the most backward. The prosperous agrarian states of Haryana \& Punjab bear that ignominy with the neighbouring industrial hubs of Delhi \& Chhattisgarh just slightly better. Uttar Pradesh has a better CSR than Maharastra \& Gujrat, while Bihar is even better than the national average.

Within states, rural areas tend to have a better CSR than urban areas. The 2008 sample Registration System numbers bears that rural areas had 918 girls for every 1,000 boys under four as opposed 905 in urban areas. The rural urban divide is largely northern \& eastern phenomenon with the sharpest divides in Chhattisgarh, Jharkhand \& Himachal Pradesh but also Gujrat. There is little urban rural difference in southern states. Breaking the numbers down further, 150 most backward districts, as identified by the central government, had far better CSRs than the rest, according to 2001 census-they had an average of 947 as against 921 for the rest. The gap between backward \& non-backward districts was particularly high in the states like Gujarat, (923 to 873) Jammu \& Kashmir (992 to 932), M.P (948 to 924),Rajasthan (936 to 905 ) and Orissa (964 to 934). This trend was not found largely in Southern states. Nor is high literacy necessarily a good proxy for a healthy gender balance. The latest census numbers show that Maharastra, with a literacy rate of almost $83 \%$, has CSR of 883 , while Chhattisgarh, with just $71 \%$ literacy (61\% for women) has CSR of 964 .

In 2001, the districts level data showed that the most literate districts with greatest access to technology had much worse CSRs than the least literate. The top 10 districts of literacy in UP had a CSR of 887 compared to the bottom 10 for whom the number was 937, a difference of 50. The same trend prevailed in Gujarat, Rajasthan, Bihar, Haryana \& West Bengal. This indicates that mere education has not been enough to correct a deep societal \& cultural bias that India seems to have against girls. The sex ratio is worst in the prosperous coastal districts. This is because selective abortion is more rampant here. The drop in girl child sex ratio may be attributed the notorious nexus of tradition \& technology. Traditionally, there is a preference for the male child. And technology is helping eliminate the girl child.

It is agonizing to know that gender bias \& deep rooted prejudice \& discrimination against girl child, which have been there down for centuries, are now found to begin in the womb itself. The girl child in the womb faces the peril of prebirth elimination i.e female foeticide. Globalization \& commercialization of the medical profession as well as human relations, propelled by large publicity in mass Medias, have also played a part making the sex-determination test \& aborting female foetus desirable. No place is safe for women, not even in their mother's wombs. They are put to death before they are born ${ }^{11}$.

\footnotetext{
${ }^{9}$ Reported by Pradhan (2011)

10 More discussion see this context Sen 1990, 2001, 2003

${ }^{11}$ www.wscpedia.org
} 


\section{Causes of Decline in Female Sex Ratio}

The imbalance in India in respect of sex ratio is more acute \& more likely the reflection of three major factors (behavioural)

(i) This imbalanced ratio is indicative of pre-natal sex determination by parents.

(ii) Infanticide as a result of parental neglect of female children in terms of foods \& health care allocation

(iii) When parents use contraceptives differently depending upon the sex composition of their existing children, such as using contraceptives only after having had a son. All the three factors reflect a strong cultural preference among Indian parents for sons over daughters. The low \& declining juvenile sex ratio in the country is a matter of grave concern not only because it violates the human rights of unborn \& infant girls but also it deprives the country of the potential economic \& social contribution of these missing women.

One might assume that improving literacy \& schooling among Indian women would work to reduce the parental preference for sons. But the evidence for this is not encouraging. Much of the evidence points to the worsening of the juvenile sex ratio with increased female education for this has to do with negative effect of female literacy on fertility. Educated women tend to have fewer children than less-educated women \& in the context of a strong son preference culture, the lower levels of fertility lead to greater pressure on couples to have boys instead of girls ${ }^{12}$.

\section{Diagnostic Procedures/Sex Selective Abortions}

The practice of aborting the female child after pre-natal sex determination is spreading fast among those sections of that society such as muslims, the tribals \& low caste Hindus-which were earlier free from the pernicious evil. It is obvious that these cultural \& historical factors can not explain the acceleration in the process of eliminating the girl child that is now rampant in all parts of the country, more so in urban \& metropolitan areas. There is enough evidence to show that the girl child in India is falling prey to the profit driven ultrasound industry \& doctors who commit foeticide. The seeds for this were sown during the 1970s when the family planning to control the population gained priority in the country's health policy. When the experts at All India Institute of Medical Science (AIMS) developed the technology for sex-determination it was touted as the panacea for India's population explosion. The fact that all the cases in which it was tested led to the elimination of the girl child was conveniently ignored. The Medical Termination of Pregnancy Act was also passed about the same time with the ostensible objective of empowering women to discard unwanted foetuses. Again, the fact that women in Indian social milieu had little choice in this matter was glossed over.The late 1970s \& the 1980s saw large scale abortions in government hospitals after sex- determination. In fact advertisements were issued on how would be parents could save themselves the cost of huge dowries by paying a paltry amount for the services of sex determination \& subsequent safe abortions. The steady decline in the sex ratio suggests that marked improvements in the economy \& literacy rates do not seem to have had any impact on this index. In fact, the easy availability of technology has accelerated the process \& the privatization of health sector has worsened the trend ${ }^{13}$. A study by Jha et al. (2006) of the centre for Global Health at the University of Taronto published in a recent issue of a British medical journal The Lancet gives an interesting inside into the scenario in India. The study has found that the girl-boy ratio fell from 906 girls per 1,000 boys in 1990 to 836 in 2005; an annual decline of 0.52 percent. The decline was much greater in families where mothers had 10 or more years of education than in those where mother had no education. It was pronounced in wealthier households than poorer households. But, if the first child had been a boy, there was no fall in the girl-boy ratio for the second child over the study period, strongly suggesting that families particularly those that are wealthier \& educated, are selectively aborting girls if their first born child is also a girl'14. The pre-natal sex determination, followed by abortion of female foetuses, is the most plausible explanation for the low sex ratio at birth in India.

\section{Statutes}

The Pre-Conception \& Pre-Natal Diagnostic Technologies (PNDT) Act ${ }^{15}$ was enacted in 1994 a fully developed industry

\footnotetext{
12 Quoted from Deolalikar 2009

${ }^{13}$ See D'Souza \& Chan, 1980 ; Park \& Cho, 1995; Kynch \& Sen, 1983 ; Das Gupta, 1987

14 See also Dhar (2011)

15 To check the decline in sex ratios and to stop female foeticide, the Pre-conception and Pre-Natal Diagnostic Techniques (Regulation and Prevention of Misuse) Act, 1996 and the amendment PNDT Act 2003 has been introduced. The main purpose has been to ban the
} 
for elimination girl child had established itself. Neither the government nor the medical fraternity seemed serious about the enforcement of the PNDT Act \& the industry continued to prosper. How inadequate has the enforcement of the PNDT Act has been judged from the fact that despite the apex court's directive that the Central Supervisory Board (CSB), set up under the Act, should meet at least once in three months, the CSB had not met once in three years till it was reconstituted last February 2011. Reports state that there were 843 cases of violence of PNDT Act during the last 17 years of which only 55 led to conviction ${ }^{16}$. A powerful Lobby of doctors \& companies selling ultrasound- machines cater to sexdetermination market. Though the number of clinics registered under the PNDT Act is around 40,000, social activists estimate the number to be much more. The Multinational Companies (MNCs) selling these machines only require an affidavit from the purchasers that these machines would not be used for sex determination. Reports say that Chinese ultrasound machines are also floating the market. The CSB has recommended sealing of all unregistered clinics \& giving the law more teeth. It has also asked the medical council of India to de-register doctors found to be indulging in sex determination \& illegal abortions. The arrival of mobile ultrasound machines has made the task even more difficult. The past performance of the Indian Medical Association \& $\mathrm{MCI}$ (Medical Council of India) in curbing the menace has been dismal. The problems of implementation are ubiquitous. The scenario is totally bleak. The collusion between people, the medical fraternity \& the administration has resulted in worsening of the sex ratio \& failure of the Act to make a difference.

\section{Patriarchal Structure}

There is strong tradition of a preference for a son \& patriarchal form of society. The system extends support to the institution of male rule \& subordination of female in the society. Patriarchy strongly influences the society, despite the constitution's attempt to bring about an egalitarian social order. It has its palpable impact in social, religious, legal, political \& economic organization of society. Women's work is also socially devalued with limited autonomy in decision making. The intersections of caste, class \& gender further worsen the situation. There has been the neglect of nutrition, health care, education \& employment for girls under the dominance of patriarchal culture. The system has spawned practices such as female infanticide, dowry, bride-burning \& sati.

In rigidly Patritineal system, main productive assets are passed through the man line, while women may be given some movable goods in the form of dowry ${ }^{17}$. Strong son preference is an inherent characteristic of this system. Son preferences can be effectively reduced if daughters are considered for inheritance. There is need to accept bilateral kinship systems, where kinship relations are maintained through male \& female lines ${ }^{18}$. Patriarchy is the not root cause of this disease; eradication can only be effected by direct attack on patriarchy.

\section{Moral Blindness}

The system being patriarchal in character, its norms would leave little choice to the girls to decide for themselves. The reduction of girls population is not because of the natural population divide but a state that is arrived through conscious choices \& the anti-girl child gender bias. Gender inequality is a burden on societies \& is often socially determined. Ironically, \& this is the paradox that it is modern and globalised society that is promoting heinous practices like female foeticide, sex detection tests \& induced abortion of female foetuses. Bringing daughters is viewed as a liability \& sons are preferred as the saviors of seven generation of ancestors ${ }^{19}$. One behaves unethically in relation to girls \& women, while maintaining a positive self-image. Ethical feeling also causes one to condone the unethical behaviour of others. Such "motivated blindness" tends to disregard issues that work against patriarchy ${ }^{20}$.

\section{Disregard for the Sanctity of Life}

Abortion, though sounds milder, is nothing but taking a person's life. Our lives come into existence by a process which is too beautiful to describe. Any one who has held a new born baby would know this fact. This process starts right in day

use of sex-selection techniques before or after conception as well as misuse of prenatal diagnostic techniques for sex selective abortions and to regulate such techniques.

${ }^{16}$ Reported by Sharma (2011).

17 for more discussion see in this context Das Gupta, et al.,2003, Agrawal, 1994

18 See Das Gupta, et al, 2003; Wuongbooosin, et al, 1996, Sowradji,et al,1996.

${ }^{19}$ Cited from Sitaram, S. (2011)

20 See for details Jacob (2011) 
one of conception, in the wombs of our mother. Therefore, taking someone body's life, even one's own child before he or she is born for reasons such as graced for a male child, want of money, avoiding social embarrassment \& unwillingness to take the responsibility of bringing up children, amount to murder. This heinous act should be abhorred at all costs. A growing disregard for the sanctity of human life has led to the liberalization of abortion laws world over.

A society has to kill its conscience before it kills its children. In the west, while the killing happens to maintain its sexual freedom, it the East it happens to satisfy its greed for having male babies. In the heinous crime, whether it is the greedy gynecologist or the radiologist or greedy family which asks for abortion, the conscience is killed first before the baby is killed. Foeticide is nothing but infanticide happening in a much earlier state. It appears as if education has not done much to arrest moral degradation of people. This is proved by the fact that abortion practices are higher among the educated lot. A hardened conscience \& disregard for the sanctity of life is the reason for widespread abortion \& female foeticide in particular.

The girl child is still looked upon as a burden, a curse, a community with limited guarantee, even in this enlightened age. The delivery date is awaited with great trepidation. The parents-in-law hover over the hapless girl, vultures waiting to swoop in case she commits the grievous sin of delivering a daughter. The husband is all set to prove his manhood \& God save his life if she proves him wrong. The fault is all hers, despite the various messages flashed on television. The ' $Y$ ' chromosome turns into the 'WHY' chromosome, since matrimony is often a matter-of-money ${ }^{21}$. The mother orders her daughter to bring a glass of milk to her brother. After a whole day of back-breaking work at home, why is she expected to take a glass of milk to her brother, who has done nothing more strenuous than studying \& playing? But of course, he is the son of the house, the apple of his parents.

\section{Family Planning Programme}

Our family planning programme gave undue importance to accepting the small family norm. Media, especially radio, television \& posters, convinced people about government programmes \& also to make use of advanced technology so that choices in family size can be ensured. The aim of population policies was to achieve a fertility decline, but in northwestern India, this decline was characterized by a strong son preference \& gender bias. The government policy pursued the acceptance of small family norm but did not take any initiative to reduce a son preference, \& this policy had an impact on the incidence of foeticide 22 .

One of reasons for the presence of fewer girls is the net wealth out flow on the occasion of a girl's marriage. Despite the Anti-dowry Act, the practice continues \& is spreading all over country. The menace of dowry deaths has increased manifold in Punjab, Haryana \& Rajasthan. In this way, a daughter becomes an avoidable social \& economic burden 23 .

\section{Discrimination Against Women in Socio-Economic Activities}

A son's utility is reflected in the economy of family labour provided by him in the family business, earning a wage \& salary through mobility, looking after old age parents \& also attracting dowry. It is evidence that in a socially segregate society, similar to India, industrialization leads to rising dowry payments through increasing within-group wealth inequality due to a movement away from the traditional occupation structure ${ }^{24}$. This reveals that a son is a most valued asset to the family, whereas girls are not given such opportunities to perform all these activities, instead, a perception of economic liability is highly attached with daughters. This has resulted in widespread practices of sex selective abortion. The wage rates also differ across the regions for males \& females \& these also affect the sex ratio ${ }^{25}$. People feel that their earnings would have enhanced as compared to the household with a daughter, if they had been a son.

\section{Ancestral Worship}

Ancestral worship adds another dimension to the need to have male offspring. Son preference is necessary to ensure one's prestige during one's life time \& after death also for performing a series of funerary rituals. People feel that they will

\footnotetext{
${ }^{21}$ See more detailed on Menon (2011)

22 See for details Das Gupta (1987)

${ }^{23}$ Bhalla (2006)

${ }^{24}$ See in this context Anderson 2003

25 World Bank (1991), Mandelbaum (1988)
} 
only be able to achieve mokshya through their sons ${ }^{26}$. These types of social order need a big reform. Religious pundits should give the preaching that the girls are as valuable as boys \& the mindset that militates against the girl child may not take place. Society should introduce a system where both sons \& daughters can perform religious rites for their parents.

In India, the state has enacted various women specific \& women related legislations for the upliftment of women \& to safeguard their interests. Various five year plans have laid greater emphasis in women's economic role, \& have also identified core development issues of women such as health, education \& employment. A great deal of attention is being paid to the states \& well-being of the girl child by the government, UN agencies, NGOs \& welfare organizations. If a girl child does not have a right to be born, then where will all these efforts will go. It is now acknowledged that these provisions are basically useful to women belonging to the educated, urban \& high- income groups and are not helping in changing the life Indian poor women. Rural customary laws continue to regulate women's right in matter of gender \& development policy. In the rural \& urban areas, parents continue to live with their sons, \& it is still rare for married women to contribute to their parent's well being ${ }^{27}$. The main reason for gender bias is female infanticide where females are not allowed to born given misunderstanding that females are looked upon as burden by the parents. Discriminations against girls are much higher where mothers are literate ${ }^{28}$. In most cases, literacy is just confined to formal degrees; mindsets are primitive. People feel that the returns of cost \& time investments in a male child will be much higher compared to a female child, who eventually moves to her husband's home after marriage.

\section{Implications}

Amartya Sen (1990), who raised the alarm of missing daughters in the nineties \& other scholars hold that sex selective abortions are not only intrinsically cruel \& reflections of low value that society places on women, but the resulting skewed ratio impedes the development of democracy and security. Democracy is a government of the people, by the people \& for the people. It rests upon fundamental human rights of equal opportunity/ treatment \& freedoms to speak, act $\&$ believe in a way that allows people to achieve their dreams. . Sen (1999) in his book Development as freedom argues that anything that negatively impacts the ability of an individual to enjoy freedom is an unfreedom which can arise from either inadequate processes or inadequate opportunities. Adverse sex ratio reveals the most glaring example of an unfreedom in which freedom is snatched away from a baby girl. In case of foeticide, the right to life itself is denied to a girl child even before she is born, rendering all his rights \& freedoms irrelevant. Apart from its threat to its democratic principles, Indian sex skewed ratio seems to impact both the treatment of Indian women in particular as well as the health of Indian democracy in general.

One of the obvious consequences of the continued skewed sex ratio would be the shortage of brides. Sociologists agree that such a state of affairs encourage abuse, notably in trafficking, drug abuse \& physical violence against women. "Put bluntly, it is a competition against scarce women". Societies with adverse female sex ratio have indicated the presence of customs like polyandry, abduction \& purchase of women. It is strongly felt that contrary to raising the status of women, adverse sex ratio would increase the incidence of rape, prostitution \& violence against women. Due to shortage of brides, men belonging to lower social class are pushed to receiving end. The poor are forced into a long or permanent bachelorhood -a status widely frowned upon in India. The poorer among the farming community in Malwa region of Punjab are forced to practice polyandry for twin reasons of scarcity of women \& for warding off the fragmentation of smaller land holding.

As stated above, the shortage of women in society leads to violence against women rather than improving their states. The situation is made more complex since couples do not wish to beget girls as they fear that it would be difficult to bring then up with dignity $\&$ also because of the continued threat of violence they may have to face. Therefore, the society is caught in a vicious circle. The fear of violence towards women is a cause for female foeticide. The prevalent patriarchal framework places an ideological bar on the discussion of alternative approaches to achieve gender equality.

In order to maintain the patriarchal order, ethics are allowed to fade away \& never given serious consideration, \& thinking \& behaviour are conditioned accordingly. Overall, male chauvinism is detrimental to women empowerment, women as an active agent for development, participation in \& guiding their own development. To deal with patriarchy in a complex society like ours may be set as the ultimate goal to address gender issue, but the process would be fairly complex \& can take a long time through dialogues \& discussions among the segments of society with a view to achieving a system where both men \& women have equal status \& say in determining the course of society as well as individual

\footnotetext{
${ }^{26}$ See Jain (2006)

27 See for details Bora (2007)

28 See for details Jha et. al (2006)
} 
family development.

\section{Necessity for Gender Impartiality}

The strict implementation of law alone will not eliminate the problem, unless the system of patriarchy is not changed. The major barrier to mainstreaming gender justice \& scaling up effective interventions is gender inequality based on social cultural issues ${ }^{29}$. Although selective abortion of female foetuses stands as a causal, still patriarchy has a major impact on the outcome. While women are guaranteed equality under the constitution, legal protection has little effect in the face of prevailing patriarchal culture. India needs to confront gender bias openly. It is true that every evil act by a human being ultimately has its source in the heart of the person. Our hearts are deceitful above all things \& no one understands it really well. In the light of this we, the human being, who were foetuses to start with, whether lawmakers or doctors or the common man, should make all our decisions, especially when it comes to abortion with a clear conscience \& should refrain from flouting the sanctity of human life.

Apart from this, the most important are wide ranging \& serious programmes to enhance the status of women \& girls ;ensuring education \& livelihood skills building for girls, ensuring economic opportunities for them, ensuring their representation in political processes \& in short, making them valuable \& equal partners with men in families, societies \& national development. Education \& affluence seem to have a decline in the sex ratio; the decline was higher in case of women with ten years or more of education than for mothers with no education. Such a trend calls for closer study of the factors that reinforce the son's preference, especially in the states \& districts with a worsening ratio.

Indiscriminate abortion of female foetuses is the reason for this skewed ratio. Naturally, if abortions were not done, there would be about 952 girls born for every 1000 boys. The exact numbers of abortions due in India, for obvious reasons, is not known. Had an equal number of male foetuses also been killed, this genocide would not have been known. It is a regrettable fact that when there are people to fight for women's right \& animal rights, there are not many who uphold the sanctity of human life. But then, this has been the trend seen since 1961, every census shows a reduction in girl child compared with the previous one. This is not "this census specific" but more a recurring \& continuing trend.

The declining trend of child sex ratio can undercut both social \& economic progress drastically. The government must take every step possible to address it, from naming \& shaming states that are the worst offenders to providing incentives for raising girl children. It is the responsibility of the state to ensure the equal economic \& social rights of all women, girls \& children, along with violence free existence for them.

Any serious view of law in the states with the worst child sex ratios should begin with quarterly reports they are required to file in diagnostic centers, laboratories, \& clinics, \& the action taken against unregistered bodies, search \& seizure, \& the outcomes of awareness campaigns. Not all states have been filing such reports regularly. The level of involvement of Laggard states in implementing the PNDT Act can be gauged from the fact that in Haryana a crucial notification in setting up Appropriate Authorities was not published in the gazette for 12 years from 1997, \& it has to be reissued as an ordinance with retrospective effect. But then, while enforcement measures may have salutary effects, the more challenging task is to make India a less male-dominated society. The place to start for that mission would be parliament and State Legislative Assemblies. Political parties must lead by enabling $33 \%$ representation for women in legislatures \& raised their visibility. Liberal scholarship for all levels of study \& improved economic security may tilt the balance for the less affluent sections.

\section{Conclusions and Suggestions}

Terming the decline in sex ratio (0-6 yrs) as an emergency, civil rights workers say there is lack of political will to address the issue which requires a national policy from the government before the situation goes out of hand. The solution is nothing but strict implementation of PNDT Act. The central supervisory board which must meet every six months has been non-existent for three years. There needs to be move towards those families who, under the influence of the rampant small family norm and son preference, stop producing children when one or two sons are born (Perwez et. al. 2012). It is important to recognize one of the reasons for preference of son over daughters is inheritance laws in India. The inheritance laws provided the right of inheriting ancestral property to only male. It is widely believed that some of worst manifestations of gender discrimination in India, such as female foeticide \& dowry can be traced back to biased inheritance laws favouring sons (Deolalikar 2009). In 1975, Kerala was the first state in the country to change its

${ }^{29}$ Quoted from Jacob (2011) 
inheritance laws to provide women the right to inherit ancestral property. During last two decades, a few stalwart states such as Andra Pradesh, Karanataka, Maharastra \& Tamil Nadu have also changed their inheritance laws. In 2004, the Indian parliament introduced \& passed Hindu succession (Amendment) Bill, which removed the discriminating provisions of the 1956 Act \& gave daughters a right to their parent's property (Singariya 2012). What is needed is overall social attitude transformation, where girls are seen as asset than liability. What is urgently required is to make change in the mindsets of the parents through sustained Information Education \& Communication (IEC). The urgent need is to tighten the existing legislations like PNDT Act, which aims at preventing female infanticide. The NGOs which aims at women empowerment should take this important issue on their agenda \& as a part of their many interventions, should bring pressure on the concerned government to implement legislations so that child sex ratio can not be adverse. There is an urgent need for women SHGs who should take active lead in educating their SHG members \& others in the society through organizing the social campaigns aggressively.

Further in reducing son preference social reformer activism as well as state policies can play an important role. Increasingly, the family size is getting smaller. The state should initiate one son \& one daughter norm, so that imbalances in the child sex ratio could be removed. The availability of reliable $\&$ affordable old age pensions, social security \& life insurance programmes in rural \& urban areas will possibly reduce the excessive dependence on sons. Had there been effective risk coping institutions in rural \& urban areas, the son would not been priotized over the daughter.

What is needed to combat the scourge of low juvenile sex ratio is a package of interventions in villages having the most imbalanced sex ratios, \& an educational curriculum at the primary \& middle school levels that highlight the importance of equal treatment for boys \& girls in the family. Even with such a package, it will take years for attitudes to change \& for the practice of pre-natal sex-selection \& neglect of female children to end. Unless India manages to reverse the decline in the juvenile sex ratio, its demographic transition will remain incomplete (Deolalikar 2009). Civil society organizations should continue to mobilize the community in order to encourage them to allow girls to be born. In order to improve sex ratio, various projects like "Meri Shakti Meri Beti" should be introduced in various states.

State of world's children 2007 is a scathing indictment of the efforts of both central \& state governments to enforce laws against sex selective abortion, as well as killing of new born girls. Campaigns to encourage people to view girl children as socially \& economically desirable do not seem to have made much of impact either. Tackling this requires a sensitization campaign along the lines of Human immunodeficiency virus infection/acquired immunodeficiency syndrome (HIVIAIDS) (Campaign). The apathetic attitude of administration coupled with inefficient legislative implementation further adds to the woes of girl child in India, facing elimination \& discrimination in their very right to life. The District collectors should take legal actions \& if possible, furnish, those "Sonography centres" who are not ready to implement "Silent observer". The steps should be initiated for promoting "Save the baby girls campaign "through the help of schools, colleges, through Nair Service Society (NSS) \& other programs. Keeping watch and taking actions like cancelling medical practice registrations, on those private doctors, who are involved in "Kill the baby girl" campaign in majority of urban, \& rural areas. Various motivational incentives should be taken to those couples who stop their issues after "One/Two" baby girls issues like reservation in school \& college admission, reservations in government jobs, housing loans with concessional interest rate to the couples with "One/two" baby girls issues, free education to the girls up to graduation. The strategies given above, if implemented sincerely, then it will help to control the declining sex ratio. Therefore, the health planners \& demographers should take this serious issue into their account in years to come.

India's declining sex ratio raises difficult questions-about the welfare of India's daughters, as well as the security of its entire people-those lawmakers, civil society representatives \& the citizens of India need to ask them. What may be at stake is the very existence of India as a democracy with a proud tradition of unity in diversity. A concerted effort by the medical fraternity, the law, political leaders, NGOs, Medias, teachers \& the community itself is the need of the hour.

\section{References}

Agarwal, Bina (1994): "a field of one's own: gender and land rights in south Asia", Cambridge: Cambridge University Press.

All India Democratic Women's Association -AIDWA (2011): "deep concern regarding further decline in child sex ratios in 2011 census", http://aidwaonline.org, accessed on June 18, 2011

Anderson, S. (2003): "Why dowry payments declined with modernization in Europe but are rising in India", Journal of Political Economy, 111(2), 269-310.

Bardhan, P. K. (1974): "On life and death questions", Economic and Political Weekly, Vol - IX No. 32-33-34, August 10, pp.1293-1304.

Becker, G. S. (1991). "A treatise on the family", Harvard University Press.

Bhat, P.N. Mari and A.J. Francis Zavier (2007): "factors influencing the use of prenatal diagnostic technique and the sex ratio at birth in India", Economic and Political Weekly 42: 2292-2303.

Bhalla, G. S. (2006): "Condition of Indian Peasantry", Delhi, National Book Trust, India 
Bora R. S. (2007): "Imbalance in Child Sex Ratio: Trends, Causes and Emerging Issues", Working Paper No 280, Institute of Economic Growth, Delhi

Chakraborty, T., \& Kim, S. (2010): "Kinship institutions and sex ratios in India", Demography, 47 (4), 989-1012.

Coale, A. (1991): "excess female mortality and the balance of the sexes in the population: an estimate of the number of 'missing females", Population and Development Review, 17 (3), 517-523.

Das Gupta et al, (2003): "Why is Son Preference So Persistent in East and South Asia? Journal of Development Studies, 40 (2), pp 153187.

Das, Gupta Monica (1987): "Selective Discrimination against Females in Rural Punja India", Population and Development Review, 13(1): $77-100$.

Dhar, Aarti (2011): "8 million children still out of school", The Hindu, April 1, 2011 New Delhi.

Dhar, Aarti (2011): "child sex ratio is the lowest since independence", The Hindu, 1st April, 2011.

D'Souza, Stan and Lincoln C. Chen (1980): "Sex differentials in mortality in rural Bangladesh," Population and Development Review 6(2): $257-270$

Dyson, T. and Moore, M. (1993): "On kinship structure, female autonomy and demographic behaviour in India", Population and Development Review, 8, 35-60.

Deolalikar, Anil B. (2009): "India in Transition: India's Falling Juvenile Sex Ratio", Center for the Advanced Study of India (CASI), University of Pennsylvania.

Duflo, E. (2001): "Schooling and Labor Market Consequences of School Construction in Indonesia: Evidence from an Unusual Policy Experiment", American Economic Review, American Economic Association, vol. 91(4), pages 795-813, September http://www.savegirlchild.org/declining sex_ratio-html, accessed on November 21 2011infochangeindia.org, accessed on 30 June 2011

Jain, A. K. 2006, The Saga of Female Foeticide in India, Socio Legal Offshoots, Delhi.

Jha Prabhat, Rajesh Kumar, Priya Vasa, Neeraj Dhingra, D. Thiruchelvam, Rahim Moinedin, (2006): "Low Male to Female Sex Ratio of Children Born in India: National Survey of 1.1 Million Households", The Lancet, Vol. 367(9506): 211-18

Klasen, S. (1994): "Inequality and Growth: Introducing Inequality-Weighted Growth Rates to Reassess Postwar U.S. Economic Performance", Review of Income and Wealth 40(3): 251-72

Mandelbaum, D. G. (1988): "Women's Seclusion and Men's Honour", Tuscon: University of Arizona Press.

Menon, Deepti (2011): "The discrimination begins early", The Indian Express, 28 April

Norberg, K. (2004): "Partnership status and the human sex ratio at birth". Proceedings of the Royal Society of London, Series B: Biological Sciences, 271(1555), 2403.

Oster, E. (2005): "Hepatitis B and the case of the missing women", Journal of Political Economy, 113(6), 1163-1216.

Perwez, S., Roger Jeffery and Patricia Jeffery (2012): "declining child sex ratio and sex-selection in India a demographic epiphany?" Economic and Political Weekly, August 18, Volume XLVII, No.33: 73-77.

Pradhan, Ashok (2011): "Drop in the girl child ratio in Orissa", The Times of India, Apr 1.

Qian, N. (2008): "Missing women and the price of tea in China: the effect of sex-specific earnings on sex imbalance", The Quarterly Journal of Economics, 123(3), 1251.

Rosenzweig, Mark R and T. Paul Schultz (1987): "fertility and investments in human capital: estimates of the consequences of imperfect fertility control in Malaysia", Bulletin Number 87-1, Economic Development Center, Department of Economics, Minneapolis and Department of Agricultural and Applied Economics, St. Paul, University of Minnesota, February.

Sen, A. (1990): "More than 100 million women are missing", New York Times, Volume 37, Number 20, Dec. 20.

Sen, A. (1990): "More Than a Hundred Million Women Are Missing", New York Review of Books, Christmas Number (20 December): 61 66.Sen, A. (1999): "Development as Freedom" Oxford University Press, 366 pages

Sen, A. (2001): "Many faces of gender inequality", Frontline, Volume 18 - Issue 22, Oct. 27 - Nov. 09.

Sen, A. (2003): "Missing Women - Revisited", British Medical Journal, 327(7427): $1297 \backslash 98$.

Sharma, Kalpana (2011): "Where have all the girls gone", The Hindu, 17th April

Singariya, M.R. (2012): "Determinants of Declining Child Sex Ratio in Rajasthan", Journal of Economics and Sustainable Development, Vol.3, No.1, (Online), www.iiste.org, accessed on 29th August 2012

Sitaram, S. (2011): "Boom economy without women?", The Hindu, 12 June.

Sowradji, Budi and Harijati Hatmadji (1996): "Ethnic Differentials in Son Preference in Indonesia; in Sex Preference for Children and Gender Discrimination in Asia", Seoul: Korea Institute for Health and Social Affairs.

Wongboosin, Kua and Vipan Prachuabmoh Ruffolo (1996): "Family Size Desires and Sex Preference for Children in Thailand', in Sex Preference for Children and Gender Discrimination in Asia", Seoul: Korea Institute for Heath and Social Affairs.

World Bank (1991): "Gender and Poverty in India: A World Bank Country Study", Washington, D. C.

www.wscpedia.org "The Declining Sex Ratio in Punjab: A Case Study of Dhreri Jattan" accessed on December 152011. 